\title{
Single Laboratory Validation of Determination of 13 Trace Elements in Rice by ICP-MS with an Overview of Challenges Encountered
}

\author{
G. U. Chandrasiri ${ }^{*}{ }^{(}$, M. N. A. Mubarak1, K. Mahatantila1, K. R. R. Mahanama² \\ ${ }^{1}$ Industrial Technology Institute, Bauddhaloka Mawatha, Colombo, Sri Lanka \\ ${ }^{2}$ Faculty of Science, University of Colombo, Colombo, Sri Lanka \\ Email: *gayaniudeshika123@gmail.com
}

How to cite this paper: Chandrasiri, G.U., Mubarak, M.N.A., Mahatantila, K. and Mahanama, K.R.R. (2019) Single Laboratory Validation of Determination of 13 Trace Elements in Rice by ICP-MS with an Overview of Challenges Encountered. American Journal of Analytical Chemistry, 10, 367-376.

https://doi.org/10.4236/ajac.2019.109025

Received: July 31, 2019

Accepted: September 2, 2019

Published: September 5, 2019

Copyright $\odot 2019$ by author(s) and Scientific Research Publishing Inc. This work is licensed under the Creative Commons Attribution International License (CC BY 4.0).

http://creativecommons.org/licenses/by/4.0/

\begin{abstract}
With the emerging concern on trace element content in rice on both toxicological and nutritional standpoints, validation of analytical method to determine both essential and toxic elements in rice is important in order to produce reliable results. Therefore, this study was aimed to validate analytical method to determine $\mathrm{As}, \mathrm{Cd}, \mathrm{Pb}, \mathrm{Hg}, \mathrm{Cr}, \mathrm{Ni}, \mathrm{Se}, \mathrm{Cu}, \mathrm{Mn}, \mathrm{Mo}, \mathrm{Fe}, \mathrm{Co}$ and $\mathrm{Zn}$ in rice while giving an overview of the challenges encountered and application of the method to analysis trace elements in selected traditional rice varieties available in Sri Lankan market. Sample digestion was carried out by microwave digestion and analysed by ICP-MS. The analytical method was validated by measuring precision, accuracy, limits of detection (LODs), limits of quantification (LOQs), working and linear range, recovery percentage and measurement uncertainty. They showed that the method is fit for its purpose as those complies with the standard method performance requirements of AOAC. Percentage of relative standard deviations (RSD) of repeatability was not greater than $9.9 \%$ and RSDs (\%) of reproducibility were not greater than $10.1 \%$ for all elements. Mean recoveries varied from $81 \%$ to $110 \%$. Limits of detections of elements were in the range of $0.04-0.8 \mathrm{mg} / \mathrm{kg}$ and LOQs were in the range of $0.05-1.2 \mathrm{mg} / \mathrm{kg}$. Expanded uncertainties of trace elements lay between $1.1 \%$ and $6.0 \%$. Good agreement with the certified values of Standard Reference Material (SRM) 1568b-Rice Flour analysed by the proposed method with recovery percentages between $89.4 \%$ and $105.7 \%$ further confirms the accuracy and traceability of the method. The distribution pattern of essential elements in all rice varieties analysed was $\mathrm{Mn}>\mathrm{Zn}>\mathrm{Fe}>\mathrm{Cu}>$ $\mathrm{Mo}>\mathrm{Se}>\mathrm{Co}$. Even though arsenic was detected in all varieties, only the mean concentration of lead of Kaluneenati exceeds the maximum level (FAO/WHO CODEX Alimentarius).
\end{abstract}




\section{Keywords}

Validation Parameters, Trace Elements, Rice, Microwave Digestion, ICP-MS

\section{Introduction}

Rice being the staple food and main dietary source of trace elements, it plays a significant role in stabilizing food security in most Asian countries including Sri Lanka [1] [2] [3]. Recently concern has been raised by consumers on potential toxic element contamination and essential element content in rice due to excessive usage of fertilizers and pesticides [1] [4] [5] [6] [7]. In previous studies, different analytical methods including dry ashing/Inductively Coupled Plasma Optical Emission Spectrometer (ICP-OES), microwave digestion/Inductively Coupled Plasma Mass Spectrometer (ICP-MS), microwave digestion/ Graphite Furnace Atomic Spectrometer and instrumental neutron activation with $k_{0}$ standardization have been used to determine the content of several trace elements in rice. Dry ashing is a time-consuming digestion technique and losses of certain volatile elements such as arsenic, mercury and lead can be occurred during the digestion compared to microwave digestion which is less time consuming and reduces losses of volatile elements. Among the detection techniques used in previous studies, ICP-OES, ICP-MS and instrumental neutron activation with $k_{o}$ standardization have the ability to analysis multi elements simultaneously while Graphite Furnace Atomic Spectrometer has only mono elemental detection. Compared to ICP-OES and instrumental neutron activation with $k_{o}$ standardization, ICP-MS has more advantages due to its ability to offer lower detection limits and a wider working range. However, most of the analytical methods including microwave digestion/ICP-MS used in those studies were validated for analysis of few toxic elements (As, $\mathrm{Cd}, \mathrm{Hg}, \mathrm{Pb}$, etc.), performing selected method performance parameters such as accuracy, recovery, LOD and LOQ. Hence, establishment of fully validated analytical method for analysis of both toxic and essential trace elements in rice covering the method performance parameters according to EUROCHEM [8], i.e. repeatability, reproducibility, accuracy, working and linear range, limit of detection, limit of quantification, recovery and measurement uncertainty is a necessity to generate reliable data on both toxicological and nutritional standpoints.

Detection of trace elements by ICP-MS with octopole based collision cell has been increasingly recognized as the analytical technique of choice, as it enables removal of most of the spectral and non-spectral interferences by kinetic energy discrimination [9]. Along with the advanced analytical instrumentation which is capable of analysing elements in food in trace level, sample preparation has also become a growing field [10]. Digestion of samples by microwave digestion is a determinative technique for complete digestion with the minimum amount of acid in a shorter time while preventing loss or contamination of the analytes 
[11]. Even with a validated method, expounding the challenges in trace element analysis of rice is also very important for routine analysis as accuracy of results produced depends on several aspects such as purity of chemicals, sample handling, cleanliness of glassware and instrument maintenance.

Therefore, the aim of this study was to validate an analytical method including measurement uncertainty for determination of 13 trace elements including toxic (As, $\mathrm{Cd}, \mathrm{Cr}, \mathrm{Hg}, \mathrm{Pb}$ and $\mathrm{Ni}$ ) and essential $(\mathrm{Cu}, \mathrm{Co}, \mathrm{Mn}, \mathrm{Se}, \mathrm{Fe}, \mathrm{Mo}$ and $\mathrm{Zn}$ ) elements in rice while expounding the challenges encountered and application of the method to analysis trace elements in selected traditional rice varieties available in Sri Lankan market.

\section{Materials and Methods}

\subsection{Reagents and Glassware}

High purity deionized water (resistivity $18.2 \mathrm{M} \Omega \cdot \mathrm{cm}^{-1}$ ) from water purification system (Thermo Scientific Barnstead, USA) was used throughout the study. Ultra pure $\mathrm{HNO}_{3}(\geq 69 \%$, Merck, Darmstadt, Germany) was used for microwave digestion. Working calibration standards were prepared by diluting $10 \mathrm{mg} / \mathrm{L}$ multi-element calibration standard (Agilent, USA) containing $\mathrm{As}, \mathrm{Cd}, \mathrm{Cu}, \mathrm{Co}$, $\mathrm{Cr}, \mathrm{Mn}, \mathrm{Ni}, \mathrm{Pb}, \mathrm{Fe}, \mathrm{Zn}, \mathrm{Mo}$ and $10.0 \mu \mathrm{g} / \mathrm{mL}$ single element calibration standard (Agilent, USA) containing Hg. In the similar way, instrument tuning solution $(100 \mu \mathrm{g} / \mathrm{L})$ and internal Standard mix $(100 \mu \mathrm{g} / \mathrm{L})$ were prepared from $10 \mu \mathrm{g} / \mathrm{mL}$ instrument tuning stock solution (Agilent, USA) containing $\mathrm{Li}, \mathrm{Co}, \mathrm{Ba}, \mathrm{TI}$ and $100 \mu \mathrm{g} / \mathrm{mL}$ internal standard mix (Agilent, USA) containing Bi, Ge, In, $\mathrm{Li}, \mathrm{Lu}$, $\mathrm{Rb}, \mathrm{Sc}, \mathrm{Tb}$ respectively. Rice samples were spiked with multi-element Certified Reference Materials (CRMs) (AccuStandard, USA) containing As, Cd, $\mathrm{Cu}, \mathrm{Co}$, $\mathrm{Cr}, \mathrm{Mn}, \mathrm{Ni}, \mathrm{Pb}, \mathrm{Fe}, \mathrm{Zn}$ and $\mathrm{Mo}$ and single element CRM (AccuStandard, USA) containing Hg. Standard Reference Material (SRM) NIST 1568B rice flour was purchased (Merck, Germany). Glassware was kept overnight in $10 \%$ (v/v $\mathrm{HNO}_{3}$ ), rinsed with deionized water before use.

\subsection{Instruments and Apparatus}

Microwave digestion oven (MAS 5, CEM, USA) was used for sample digestion. Inductively Coupled Plasma Mass Spectrometer (Agilent 7900, Japan) was used for determination of trace elements.

\subsection{Rice Samples}

Rice samples were collected from six brands of each variety available in super markets and retailers in Sri Lankan market.

\subsection{Sample Preparation}

Approximately $0.5 \mathrm{~g}$ of homogenized powdered rice sample was weighed into a dry, clean teflon digestion vessel and $10.0 \mathrm{~mL}$ of ultra-pure $>69 \%$ nitric acid was added. Digestion was carried out according to the programme given in Table 1. 
Table 1. Operating conditions for the microwave digestion oven.

\begin{tabular}{ccccc}
\hline Stage & Power $(\mathrm{W})$ & Temperature $\left({ }^{\circ} \mathrm{C}\right)$ & Ramp time $(\mathrm{min})$ & Hold time $(\mathrm{min})$ \\
\hline 1. & 800 & 180 & 30 & 30 \\
2. & \multicolumn{4}{c}{ Cooling $0 \mathrm{~W}, 30 \mathrm{~min}$} \\
\hline
\end{tabular}

The digested sample was transferred to a $25 \mathrm{~mL}$ volumetric flask through a No. 542 Whatman filter paper. Then the filter paper was washed with deionized water and made up to the mark with deionized water.

For investigating repeatability and recovery of the analytical method samples were spiked with multi-element and single element CRMs in order to get final concentrations of $10 \%, 50 \%$ and $80 \%$ of the highest working calibration standard of each element. For each spiked level ten independent replicates were carried out.

Reproducibility was performed using two independent replicated spiked samples at each spiked level, i.e. $10 \%, 50 \%$ and $80 \%$ of the highest working calibration standard of each element by two different analysts within the laboratory. Ten independent reagent blanks fortified at concentration of lowest working calibration standard of each element were performed to determine limits of detection (LODs) and limits of quantification (LOQs).

\subsection{Determination of Trace Elements in Rice}

Inductively Coupled Plasma Mass Spectrometer was calibrated using five external working standards in the range of of $1.00-200 \mu \mathrm{g} / \mathrm{L}$ for As, Cd, Pb, Cr, Ni, Se, Cu, Mn, Fe, Mo, Co, $1.00-25 \mu \mathrm{g} / \mathrm{L}$ for Hg, $10-200 \mu \mathrm{g} / \mathrm{L}$ for Zinc and $10-$ $500 \mu \mathrm{g} / \mathrm{L}$ for Fe. Concentrations of elements of spiked samples, fortified reagent blanks, blank samples, market samples and SRM were analyzed by ICP-MS under the operating conditions given in Table 2. All the measurements were carried out with the internal standard at the concentration of $100 \mu \mathrm{g} / \mathrm{L}$.

Concentrations of elements in blank samples were deducted from all measurements. Repeatability and reproducibility were evaluated by calculating relative standard deviations (RSDs) at each spiked level. Mean recovery percentage was calculated at each spiked level. Limits of detection were calculated as sum of mean and three times of standard deviations of fortified reagent blanks and the LOQs as sum of mean and five times of standard deviations of fortified reagent blanks. The linearity of the calibration curve was evaluated by the correlation coefficient $\left(\mathrm{R}^{2}\right)$ of the calibration curves.

\section{Results and Discussion}

The overall performance of the proposed analytical method is summarized in Table 3. As both repeatability and reproducibility (within the laboratory) are generally dependent on analyte concentration [8], they were performed at three different concentrations (low, medium and high) covering the whole working range. Relative standard deviations (\%) of repeatability was not greater than $9.9 \%, 6.7 \%$ and $5.9 \%$ for low, middle and high spiked concentrations 
Table 2. Inductively coupled plasma mass spectrometer operating conditions.

\begin{tabular}{cc}
\hline Parameter & He mode \\
\hline Plasma mode & General purpose \\
RF power $(\mathrm{W})$ & 1500 \\
RF matching & $1.80 \mathrm{~V}$ \\
Sample depth $(\mathrm{mm})$ & 11 \\
Plasma gas flow rate (L/min) & 0.90 \\
Auxiliary gas flow rate $(\mathrm{L} / \mathrm{min})$ & 1.06 \\
Nebulizer gas flow rate $(\mathrm{L} / \mathrm{min})$ & 5.0 \\
Helium cell gas flow rate $(\mathrm{L} / \mathrm{min})$ & Autotune \\
Lens tune & 5 \\
Energy discrimination $(\mathrm{V})$ & 5.0 \\
\hline
\end{tabular}

Table 3. Precision, recovery (\%) LOD, LOQ, working range, correlation coefficient and expanded uncertainties of elements at different spiked levels.

\begin{tabular}{|c|c|c|c|c|c|c|c|c|c|c|c|c|c|c|}
\hline \multirow{4}{*}{ Element } & \multicolumn{14}{|c|}{ Parameter (unit) } \\
\hline & \multicolumn{6}{|c|}{$\begin{array}{l}\text { Repeatability (RSD \%) within laboratory } \\
\text { reproducibility (RSD \%) }\end{array}$} & \multicolumn{3}{|c|}{ Recovery (\%) } & \multirow{3}{*}{$\begin{array}{c}\text { LOD } \\
(\mathrm{mg} / \mathrm{kg})\end{array}$} & \multirow{3}{*}{$\begin{array}{c}\text { LOQ } \\
(\mathrm{mg} / \mathrm{kg})\end{array}$} & \multirow{3}{*}{$\begin{array}{l}\text { Working } \\
\text { range } \\
(\mathrm{mg} / \mathrm{kg})\end{array}$} & \multirow{3}{*}{$\begin{array}{l}\text { Correlation } \\
\text { coefficient }\end{array}$} & \multirow{3}{*}{$\begin{array}{c}\text { Expanded } \\
\text { uncertainties } \\
(\mathrm{U}(\%)(\mathrm{k}=2))\end{array}$} \\
\hline & \multicolumn{9}{|c|}{ Spiked level concentration (mg/kg) } & & & & & \\
\hline & 1.00 & 5.00 & 8.00 & 1.00 & 5.00 & 8.00 & 1.00 & 5.00 & 8.00 & & & & & \\
\hline As & 5.3 & 2.2 & 1.8 & 6.1 & 2.8 & 2.5 & 105.7 & 96.4 & 87.6 & 0.052 & 0.054 & $0.05-10.00$ & 0.9996 & 2.3 \\
\hline $\mathrm{Cd}$ & 2.1 & 1.0 & 1.9 & 2.8 & 1.3 & 2.4 & 96.7 & 85.5 & 99.6 & 0.055 & 0.057 & $0.05-10.00$ & 1.0000 & 1.1 \\
\hline $\mathrm{Pb}$ & 3.9 & 2.1 & 1.7 & 4.3 & 2.7 & 1.9 & 90.4 & 93.1 & 92.2 & 0.068 & 0.074 & $0.05-10.00$ & 0.9997 & 3.0 \\
\hline $\mathrm{Cr}$ & 8.6 & 5.8 & 1.8 & 9.9 & 6.7 & 2.2 & 100.5 & 102.6 & 98.4 & 0.066 & 0.070 & $0.05-10.00$ & 0.9999 & 3.7 \\
\hline $\mathrm{Ni}$ & 9.9 & 4.5 & 3.6 & 10.1 & 5.0 & 3.8 & 90.4 & 83.8 & 96.6 & 0.076 & 0.080 & $0.05-10.00$ & 0.9998 & 3.1 \\
\hline $\mathrm{Se}$ & 4.8 & 4.0 & 5.9 & 6.9 & 4.8 & 7.7 & 99.5 & 100.6 & 101.0 & 0.076 & 0.090 & $0.05-10.00$ & 0.9996 & 4.1 \\
\hline $\mathrm{Cu}$ & 1.6 & 2.2 & 2.0 & 3.9 & 2.6 & 2.4 & 110.2 & 95.4 & 98.0 & 0.073 & 0.083 & $0.05-10.00$ & 0.9997 & 1.4 \\
\hline $\mathrm{Mn}$ & 7.2 & 6.7 & 5.0 & 8.8 & 7.4 & 6.3 & 97.5 & 93.2 & 95.7 & 0.065 & 0.075 & $0.05-10.00$ & 0.9999 & 4.5 \\
\hline Mo & 5.7 & 1.6 & 2.8 & 5.9 & 1.9 & 3.7 & 98.2 & 81.0 & 94.8 & 0.058 & 0.062 & $0.05-10.00$ & 0.9999 & 2.1 \\
\hline Co & 4.1 & 4.8 & 1.6 & 4.8 & 7.4 & 1.9 & 103.5 & 97.2 & 99.0 & 0.056 & 0.060 & $0.05-10.00$ & 0.9997 & 3.4 \\
\hline \multirow[t]{3}{*}{$\mathrm{Zn}$} & 5.1 & 3.1 & 4.9 & 5.5 & 3.6 & 5.2 & 100.4 & 94.1 & 94.7 & 0.716 & 0.985 & $0.5-10.00$ & 0.9997 & 4.8 \\
\hline & \multicolumn{9}{|c|}{ Spiked level concentration (mg/kg) } & & & & & \\
\hline & 0.125 & 0.625 & 1.00 & 0.125 & 0.625 & 1.00 & 0.125 & 0.625 & 1.00 & & & & & \\
\hline \multirow[t]{2}{*}{$\mathrm{Hg}$} & 7.9 & 3.3 & 2.6 & 8.1 & 3.6 & 2.9 & 87.0 & 84.5 & 98.7 & 0.042 & 0.048 & $0.05-2.50$ & 0.9999 & 2.4 \\
\hline & 2.5 & 12.5 & 20.0 & 2.5 & 12.5 & 20.0 & 2.5 & 12.5 & 20.0 & & & & & \\
\hline $\mathrm{Fe}$ & 5.6 & 2.4 & 1.6 & 7.0 & 2.6 & 1.9 & 81.0 & 82.3 & 105.4 & 0.786 & 1.217 & $0.5-25.00$ & 0.9996 & 6.0 \\
\hline
\end{tabular}


of all 13 elements analysed. These RSD \% values are within the expected RSDs of AOAC Official Methods of Analysis, i.e. $11 \%$ for $1 \mathrm{mg} / \mathrm{kg}$ and $7.3 \%$ for $10 \mathrm{mg} / \mathrm{kg}$ [12]. Thus it shows a good agreement between the results of successive measurements performed. Relative standard deviations (\%) of reproducibility was not greater than $10.1 \%, 7.4 \%$ and $7.7 \%$ for low, middle and high spiked concentrations of all 13 elements analysed. Reproducibility of the analytical method within the laboratory was satisfactory since the RSD values were within the Horwitz equation values (RSD Horwitz) for specific concentration that is $16 \%$ for 1.00 $\mathrm{mg} / \mathrm{kg}$ and $11 \%$ for $10 \mathrm{mg} / \mathrm{kg}$. Mean recoveries varied from $81 \%$ to $110 \%$, indicating that results for all elements determined were within the recovery percentages in the standard method performance requirements of AOAC Official Methods of Analysis [12], which comprise the range between $80 \%$ and $110 \%$ for analyte concentrations between 1 to $10 \mathrm{mg} / \mathrm{kg}$.

Concentrated nitric acid being a powerful oxidizing acid and nitrating agent, it has the ability to dissolve most metals to form soluble metal nitrates. Hence it was the primary choice for microwave digestion in the proposed method.

However, in previous studies a mixture of nitric acid and hydrogen peroxide was used for digestion [5] [11] [13], as oxidizing strength of nitric acid can be increased by the addition of hydrogen peroxide. However, results of those studies have shown that mean recoveries of As and Cd were $114.2 \%$ and $127.3 \%$ respectively which were above the upper limit of satisfactory mean recovery range. Results of the proposed method show satisfactory mean recoveries for each element analysed when nitric acid is used as an oxidant alone for the digestion of rice under the operating conditions of the microwave digestion oven given in Table 1. Physical interferences due to differences in viscosity, surface tension and dissolved solids between samples and calibration standards were corrected with the use of internal standard mixture [14]. Memory interferences which occurs when analytes from a previous sample or standard are measured in the current sample were minimized by rinsing the sample introduction system with $2 \%$ $\mathrm{HNO}_{3}$ followed by deionized water between samples in the run sequence. In trace element analysis, minimization of potential contamination of analytes of interest from reagents, glassware and equipment is important for the accuracy of the results produced. Therefore, ultra pure nitric acid and type 1 deionized water were used for throughout the study. Regular maintenance of ICP-MS according to manufacturer's recommendation such as checking the argon, helium levels and peristaltic pump tubing for damage, cleaning sampling, skimmer cones and ion lenses, replacement of argon gas filters, plasma, auxiliary gas tubing when necessary etc. were carried out.

Results of repeatability, reproducibility and recovery percentage confirms that the method is precise and accurate throughout the working range as most of the interferences were minimized. LODs and LOQs obtained for each element are given in Table 3. The values were below the limits established in CODEX General Standard Contaminants and Toxins in Food and Feed [15]. Correlation coefficient values of calibration curves of all of the elements studied were higher 
than $>0.9996$, as shown in Table 4 . Hence linearity of calibration curves of each element was satisfactory [14]. Evaluation of linearity and working ranges of elements analysed are useful to take decision on what degree of calibration is required when using the proposed method on a day-to-day basis and its ability to provide results which are directly proportional to the concentrations of the elements present in the samples.

Even with a state of the art instrument ICP-MS which reduces most of the interferences, accurate quantification of certain elements specially Fe and $\mathrm{Zn}$ is still very challenging. According to the previous study, $\mathrm{Zn}$ was being leached from their walls within 24 hours even stored in polypropylene containers [16]. Therefore, in order to minimize leaching, analysis was carried out immediately after sample digestion. The concentrations of $\mathrm{Fe}$ and $\mathrm{Zn}$ in rice are higher when compared to other essential elements present. Hence working ranges of $\mathrm{Zn}$ and Fe were selected between $10-200 \mu \mathrm{g} / \mathrm{L}$ and $10-500 \mu \mathrm{g} / \mathrm{L}$ which were higher compared to the working ranges of other essential elements analysed in order to obtain satisfactory mean recoveries. Estimation of the uncertainty of the measurement of 13 mentioned trace elements in rice lay between $1.1 \%$ and $6.0 \%$ based on the bottom-up (GUM) approach [17] [18]. The highest uncertainty was obtained for Fe and lowest uncertainty was obtained for Cd.

Rice flour SRM which ideally matches the sample matrix of interest and traceable to NIST was also analysed with the market rice samples in order to assess the accuracy of the proposed method and maintain traceability. Results of analysis of SRM are given in Table 4. It shows that there was a good agreement with the certified values of SRM for As, $\mathrm{Cu}, \mathrm{Fe}, \mathrm{Mn}, \mathrm{Mo}$, Se and $\mathrm{Zn}$ analysed by the proposed method with recovery percentages between $89.4 \%$ and $105.7 \%$. In comparison to current detection techniques ICP-OES, Flame Atomic Absorption Spectrometry (FAAS) and Graphite Furnace Atomic Absorption Spectrometry (GFAAS), ICP-MS has the ability to detect larger number of elements in lower detection limits in wider dynamic linear range.

Table 5 represents mean concentrations of trace elements in traditional rice

Table 4. Results of SRM with recovery percentage.

\begin{tabular}{cccc}
\hline Element & Certified value $\pm \mathrm{U}(\mathrm{mg} / \mathrm{kg})$ & Obtained value $\pm \mathrm{SD}(\mathrm{mg} / \mathrm{kg})$ & Recovery \% \\
\hline $\mathrm{Hg}$ & $0.00591 \pm 0.00036$ & $0.00526 \pm 0.00291^{\mathrm{a}}$ & 89.0 \\
$\mathrm{Cd}$ & $0.0224 \pm 0.0013$ & $0.0223 \pm 0.0044^{\mathrm{a}}$ & 99.4 \\
$\mathrm{As}$ & $0.285 \pm 0.014$ & $0.256 \pm 0.013$ & 89.4 \\
$\mathrm{Cu}$ & $2.35 \pm 0.16$ & $2.33 \pm 0.15$ & 99.2 \\
$\mathrm{Fe}$ & $7.42 \pm 0.44$ & $7.84 \pm 1.31$ & 105.7 \\
$\mathrm{Mn}$ & $19.2 \pm 1.8$ & $19.0 \pm 0.8$ & 99.0 \\
$\mathrm{Mo}$ & $1.451 \pm 0.048$ & $1.26 \pm 0.028$ & 89.8 \\
$\mathrm{Se}$ & $0.365 \pm 0.029$ & $0.383 \pm 0.052$ & 105.0 \\
$\mathrm{Zn}$ & $19.42 \pm 0.26$ & $18.49 \pm 1.79$ & 95.2 \\
$\mathrm{Co}$ & $0.0177 \pm 0.0005$ & $0.0180 \pm 0.0008^{\mathrm{a}}$ & 101.7 \\
$\mathrm{~Pb}$ & $0.008 \pm 0.003$ & $0.005 \pm 0.002^{\mathrm{a}}$ & 61.0 \\
\hline
\end{tabular}

a. Concentration of the element lower than LOD. 
Table 5. Mean concentrations of elements in traditional rice varieties.

\begin{tabular}{|c|c|c|c|c|c|}
\hline \multirow[b]{2}{*}{ Element } & \multirow{2}{*}{$\begin{array}{c}\text { Maximum } \\
\text { level } / \mathrm{mg} / \mathrm{kg} \\
(\mathrm{FAO} / \mathrm{WHO} \\
\text { CODEX Alimentarius) }\end{array}$} & \multicolumn{4}{|c|}{ Rice variety } \\
\hline & & $\begin{array}{l}\text { Suwadel } \\
\text { (White) }\end{array}$ & $\begin{array}{l}\text { Kaluheenati } \\
\text { (Brown) }\end{array}$ & $\begin{array}{l}\text { Pachchaperuman } \\
\text { (Brown) }\end{array}$ & $\begin{array}{c}\text { Madathawalu } \\
\text { (Brown) }\end{array}$ \\
\hline As & 0.2 & $0.085 \pm 0.02$ & $0.13 \pm 0.10$ & $0.12 \pm 0.05$ & 0.07 \\
\hline $\mathrm{Cd}$ & 0.4 & $0.14 \pm 0.08$ & $0.07 \pm 0.01$ & $\mathrm{ND}<0.06$ & $\mathrm{ND}<0.06$ \\
\hline $\mathrm{Pb}$ & 0.2 & $\mathrm{ND}<0.07$ & 3.47 & $\mathrm{ND}<0.07$ & $\mathrm{ND}<0.07$ \\
\hline $\mathrm{Hg}$ & 0.1 & $\mathrm{ND}<0.05$ & $\mathrm{ND}<0.05$ & $\mathrm{ND}<0.05$ & $\mathrm{ND}<0.05$ \\
\hline $\mathrm{Cr}$ & - & $\mathrm{ND}<0.07$ & 0.11 & $\mathrm{ND}<0.07$ & $0.37+0.37$ \\
\hline $\mathrm{Ni}$ & - & $\mathrm{ND}<0.08$ & $\mathrm{ND}<0.08$ & $\mathrm{ND}<0.08$ & $\mathrm{ND}<0.08$ \\
\hline $\mathrm{Zn}$ & - & $15.51 \pm 3.72$ & $18.91 \pm 4.96$ & $17.39 \pm 3.40$ & $18.05 \pm 3.90$ \\
\hline $\mathrm{Fe}$ & - & $6.28 \pm 5.87$ & $10.93 \pm 7.88$ & $14.89 \pm 9.99$ & $9.91 \pm 5.24$ \\
\hline $\mathrm{Se}$ & 0.3 & $0.11 \pm 0.05$ & $0.15 \pm 0.12$ & $\mathrm{ND}<0.09$ & $0.09 \pm 0.01$ \\
\hline $\mathrm{Cu}$ & - & $2.28 \pm 0.51$ & $3.00 \pm 1.28$ & $2.45 \pm 0.36$ & $2.31 \pm 0.29$ \\
\hline $\mathrm{Mn}$ & - & $16.37 \pm 5.29$ & $21.10 \pm 4.90$ & $24.01 \pm 3.02$ & $22.35 \pm 4.81$ \\
\hline Mo & - & $0.69 \pm 0.18$ & $0.82 \pm 0.33$ & $0.54 \pm 0.34$ & $0.48 \pm 0.04$ \\
\hline Co & - & 0.11 & $0.07 \pm 0.01$ & $0.09 \pm 0.03$ & $0.08 \pm 0.02$ \\
\hline
\end{tabular}

varieties. In all traditional rice varieties, $\mathrm{Mn}$ has the highest mean concentration in the range of $16.37-24.01 \mathrm{mg} / \mathrm{kg}$ followed by $\mathrm{Zn}>\mathrm{Fe}>\mathrm{Cu}>\mathrm{Mo}>\mathrm{Se}>\mathrm{Co}$ in the ranges of $15.51-18.91,6.28-14.89,2.28-3.00,0.48-0.82,<0.09-0.15$ and $0.07-0.11$ respectively. Even though arsenic was detected in all rice varieties, only the mean concentration of lead of Kaluneenati exceeds the maximum permissible level.

\section{Conclusion}

The method performance parameters have demonstrated that the method fits for determination of trace elements in rice. The method can be used to determine above 13 trace elements in rice with acceptable recovery percentage range of $80 \%-110 \%$ and correlation coefficient values of calibration curves of the elements greater than $>0.9996$. Good agreement with the certified values of SRM with recovery percentages between $89.4 \%$ and $105.7 \%$ further confirms the accuracy and traceability of the method. Expanded uncertainties of 13 trace elements estimated lay between $1.1 \%$ and $6.0 \%$. With the validated method, proper use of pure chemicals, sample handling, appropriate sample dissolution, cleanliness of glassware in order to avoid contamination and instrument maintenance are the challenges that can be encountered in routine analysis as accuracy of results produced depends on them. The distribution pattern of essential elements in all traditional rice varieties analysed was $\mathrm{Mn}>\mathrm{Zn}>\mathrm{Fe}>\mathrm{Cu}>\mathrm{Mo}>\mathrm{Se}>\mathrm{Co}$. Even though arsenic was detected in all rice varieties, only the mean concentration of lead of Kaluneenati exceeds the maximum permissible level. 


\section{Acknowledgements}

The authors wish to thank Industrial Technology Institute for financial support through treasury grant TG 18/163.

\section{Ethical Approval}

This article does not contain any studies with human participants or animals performed by any of the authors

\section{Conflicts of Interest}

G. U. Chandrasiri declares that she has no conflict of interest. M. N. A. Mubarak declares that he has no conflict of interest. K. Mahatantila declares that she has no conflict of interest. K. R. R. Mahanama declares that he has no conflict of interest.

\section{References}

[1] Navarathna, N.M.C.M., Parthipan, R., Pathiratne, K.A.S., De Silva, D.S.M. and Wickramasinghe, W.M.D.A.B. (2016) Content of Heavy Metals; Cadmium, Chromium and Lead in Selected Rice Varieties (Oryza sativa L.) Grown under Different Agricultural Management Systems. Chemistry in Sri Lanka, Institute of Chemistry Ceylon, Sri Lanka.

[2] Sebastian, A. and Prasad, M.N.V. (2015) Trace Elements Management in Rice. Agronomy, 5, 374-404. https://doi.org/10.3390/agronomy5030374

[3] Jayasekera, R. and Freitas, M.C. (2005) Concentration Levels of Major and Trace Elements in Rice from Sri Lanka as Determined by the $k_{o}$ Standardization Method. Biological Trace Element Research, 103, 83-96. https://doi.org/10.1385/BTER:103:1:083

[4] Chandrajith, R., Dissanayake, N. and Dissanayake, C.B. (2012) Arsenic and Other Heavy Metals in Rice from Sri Lanka-Preliminary Results with ICP-MS. International Symposium on Water Quality and Human Health: Challengers Ahead, PGIS, Peradeniya, Sri Lanka.

[5] Diyabalanage, S., Navarathna, T., Abeysundara, H.T.K., Rajapakse, S. and Chandrajith, R. (2016) Trace Elements in Native and Improved Paddy Rice from Different Climatic Regions of Sri Lanka: Implications for Public Health. SpringerPlus, 5, 1864. https://doi.org/10.1186/s40064-016-3547-9

[6] Satpathy, D., Reddy, M.V. and Dhal, S.P. (2014) Risk Assessment of Heavy Metals Contamination in Paddy Soil, Plants, and Grains (Oryza sativa L.) at the East Coast of India. BioMed Research International, 2014, Article ID: 545473. https://doi.org/10.1155/2014/545473

[7] Mataveli, L.R.V., Buzzo, M.L., Arauz, L.J.D., Carvalho, M.D., Arakaki, E.E.K., Matsuzaki, R. and Tiglea, P. (2016) Total Arsenic, Cadmium and Lead Determination in Brazilian Rice Samples Using ICP-MS. Journal of Analytical Methods in Chemistry, 2016, Article ID: 3968786. https://doi.org/10.1155/2016/3968786

[8] EUROCHEM (1998) The Fitness for Purpose of Analytical Methods-A Laboratory Guide to Method Validation and Related Topics.

[9] McCurdy, E. and Woods, G. (2004) The Application of Collision/Reaction Cell Inductively Coupled Plasma Mass Spectrometry to Multi-Element Analysis in Variable Sample Matrices, Using He as a Non-Reactive Cell Gas. Journal of Analytical 
Atomic Spectrometry, 19, 607-615. https://doi.org/10.1039/b312250f

[10] Bader, N.R. (2011) Sample Preparation for Trace Element Analysis by Graphite Furnace Atomic Absorption Spectroscopy (GFAAS): An Overview. Der Chemica Sinica, 2, 211-219.

[11] Jalbani, N., Aftab, A.K., Bhutto, S., Ahmed, F. and Mahroze, A.K. (2014) Evaluation of Toxic Elements in Rice (Oryza sativa) Commercially Available in Pakistan: Multivariate Study. International Food Research Journal, 21, 255-261.

[12] Association of Official Agricultural Chemists (AOAC) (2016) Official Methods of Analysis Guidelines for Standard Method Performance Requirements.

[13] Perera, M.A.K.K.P. (2018) Determination of Arsenic and Cadmium in Sri Lankan rice Samples by Inductively Coupled Plasma Mass Spectrometry (ICP-MS).

[14] Gottler, R.A. (2017) Standard Methods for the Examination of Water and Waste Water. Quality Assurance/Quality Control, 23rd Edition, American Public Health Association, American Water Works Association, Water Environment Federation, 3-3-3-8.

[15] FAO/WHO (1995) CODEX General Standard Contaminants and Toxins in Food and Feed. CODEX STAN 193-1995, 31-36.

[16] Zywicki, R., Connelly, R. and Sullivan, D. (2014) Challenges of Ultra-Trace Elemental Analysis by ICP-MS. AOAC International, Rockville, MD, 23 September 2014.

https://www.covance.com/content/dam/covance/assetLibrary/posters/ZywickiAOA C14.pdf

[17] Tanase, I.G., Popa, E.D., Udristioiu, G.E., Bunaciu, A.A. and Enein, H.Y.A. (2015) Estimation of the Uncertainty of the Measurement Results of Some Trace Levels Elements in Document Paper Samples Using ICP-MS. RSC Advances, 5, 11445-11457. https://doi.org/10.1039/C4RA12645A

[18] EURACHEM/CITAC (2000) Quantifying Uncertainty in Analytical Measurement, 2nd Edition. 